\title{
Nuchal Translucency Screen
}

National Cancer Institute

\section{Source}

National Cancer Institute. Nuchal Translucency Screen. NCI Thesaurus. Code C92837.

An ultrasonic examination of the fetus in the late first trimester to measure the clear space at the back of the fetal neck to assess risk of genetic or cardiac abnormalities. 